\title{
A Predictive Model for the US Non-profit Market; A Macro to a Micro Perspective
}

\author{
Francisco J. Quevedo ${ }^{1 *}$, Andrea Katherine Quevedo-Prince ${ }^{2}$ \\ ${ }^{1}$ Lubin School of Business, Pace University, New York \\ ${ }^{2}$ School of Health Sciences, Pace University, New York \\ *Corresponding author email: fquevedo@pace.edu
}

Received: 24 August 2018 / Revised: 01 December 2018 / Accepted: 21 January 2019 / Published: 31 January 2019

\begin{abstract}
The Non-Profit Sector contributes almost \$1 trillion to the US economy, representing 5.4\% of GDP, and generating over 12 million jobs in 2017. Researchers suggest that a better understanding of the factors that affect fundraising would be of great interest to policy makers and fundraisers. However, the workings of the sector are subject of much debate. Some relate its size to the Theory of Government Failure, while others propose that government funding does have a positive effect on revenues. Some have suggested they swing with Gross Domestic Product (GDP), but others contradict this view and contend that macroeconomic variables do not affect short-run dynamics. Some research found that non-profit revenues react more to economic upswings than downturns, but nationwide organizations relate the ups-and-downs to certain events, as they influence public awareness. Predictive modeling overall has focused on big-donor analytics, aimed at identifying potential sponsors. Our research set out instead to define a working model for the US Non-Profit Sector. After an exhausting search, we located complete time series for an emblematic segment, the environmental cause, Factor Analysis allowed us to pinpoint the independent variables. We found that Non-Profit Revenues (NPR) depend largely on Public Awareness, as measured by TV coverage, and on Disposable Personal Income (DPI), specifically:$$
\mathrm{NPR}=-4401.542+528.327(\mathrm{DPI})+23.121(\text { TVCoverage })+\varepsilon
$$

We replicated prior research, which sought out relationships between macro-economic variables and NPR. That study had discarded the correlation between GDP and NPR as obvious, but did not explore DPI as the determining factor, and stuck to single variable searches, finding a correlation between the Standard \& Poors index and lagged NPR figures, with a correlation coefficient of 0.636 . Our model's Pearson's R came up to 0.935 , with perfect significance levels. Confirmatory Factor Analysis reaffirmed the fit of our equation, with an $\mathrm{R}^{2}$ of 0.87 .
\end{abstract}

Keywords: Non-profit revenue, Fundraising, Fundraiser, Donor, Predictive modeling, Social cause, Environment

\section{Introduction}

The Non-Profit Sector represents 5.4\% of total GDP in the US. Matsunaga and Yamauchi (2004) state that nonprofits have become widely recognized by researchers as having a critical and distinctive role in contemporary society; in the past, they say, the sector had been treated as a residual of other economic factors and activities, but has been recently, and with increasing consistency, thought of as an independent sector in its own right. Sergeant (2010) said that the need for the development of a comprehensive model of giving behavior has never been greater.

According to List (2011), the market revolves around three major players: (1) the donors, who provide the resources to charities. These can be individuals, corporations, public institutions, and non-government organizations (NGOs); (2) charitable organizations, which develop strategies to attract resources and allocate those resources; and (3) the government, which decides on the tax treatment of individual 
contributions, the level of government grants to various charities, and what public goods to provide directly by itself.

Berman, Brooks and Murphy (2006) found that percentage changes in funding from year to year are relatively stable and are thus capable of being modeled using standard statistical techniques. They suggest that non-profit revenues will depend on a cause's or an organization's public profile, networking, especially with religious organizations, and the sum of independent funding sources, including government support, that help diversify and stabilize fundraising in economic downturns.

The scope of this project involves the dynamics of the non-profit sector, from a macro perspective, causespecific fundraising, a segmented view by sectors, and individual giving, which takes us to the micro level. The purpose of this research is to determine what variables come into play to push non-profit revenues, and which factors act as moderators. We start by taking into account metrics such as GDP, and disposable income, to look for relationships between public awareness, regarding specific social causes, and non-profit revenues, and then would go to the micro level, looking to define what variables make the individual donor give to one or another cause.

It must be noted that non-profit organizations can raise funds through membership fees, patient and tuition charges (the case of hospitals and colleges), ticket sales (sports and museums), crowd-funding efforts, payment for services (like consulting, for instance), and donations.

We focused on this last aspect of fundraising, which amounts to almost one third of total NGO revenues. Evidently, some sectors are more dependent on public and private donations than others are, according to Zappalà and Lyons (2006), who -as a matter of fact- highlighted the scarce flow of research on the nonprofit sector.

Indeed, research has focused more on the micro than the macro view. Curry, Rodin and Carlson (2012), for instance, hypothesized that organizations that operated on transformational approaches to fundraising have fared significantly better than those, which operate on a more transactional basis. They also suggested that the greater physical proximity of the donor base of an organization would positively affect fundraising. Lastly, they posited that regional economic stress patterns would influence fundraising effectiveness, with greater economic stress leading to decreases in fundraising effectiveness. This would be the only macro variable the authors explore.

As Nissan, Castaño and Carrasco (2012) suggest, some theoretical work, however, has emerged to explain the macro perspective, that is, the differences in scale, presence, composition or financing of non-profits across countries; most of them inspired by the classical argument of Government Failure, others centered in the supply side of non-profits. The authors go on to suggest a model that includes public funding, as the first variable, adding social capital (the opposite of government failure), per capita income, and entrepreneurial activity to the equation.

In trying to develop a theoretical model, McKeever (2013) states that the Situational Theory of Publics has direct application in fundraising. According to it, three independent variables-problem recognition, constraint recognition, and involvement-predict two dependent variables-information seeking and information processing. Problem recognition is similar to (public) awareness, which is a major factor in our hypotheses. "Problem recognition" is that moment when people realize that something should be done about an issue or situation and stop to think about what to do. Constraint recognition refers to people's perceptions of obstacles in the way of acting related to the issue or situation, and involvement is defined as the extent to which people personally connect with the issue or situation. Information seeking, and processing can include passive or active forms of communication.

McKeever also stated that it is not surprising that past participation would predict future support for and or participation in fundraising. All of this is unquestionably valuable for nonprofit organizations. Trying to increase awareness, participation, support, and advocacy efforts is crucial to their particular mission or cause. 


\section{The Sector's Statistics}

As can be seen on Figure 1 below, donations have risen, yes, but they also fluctuate.

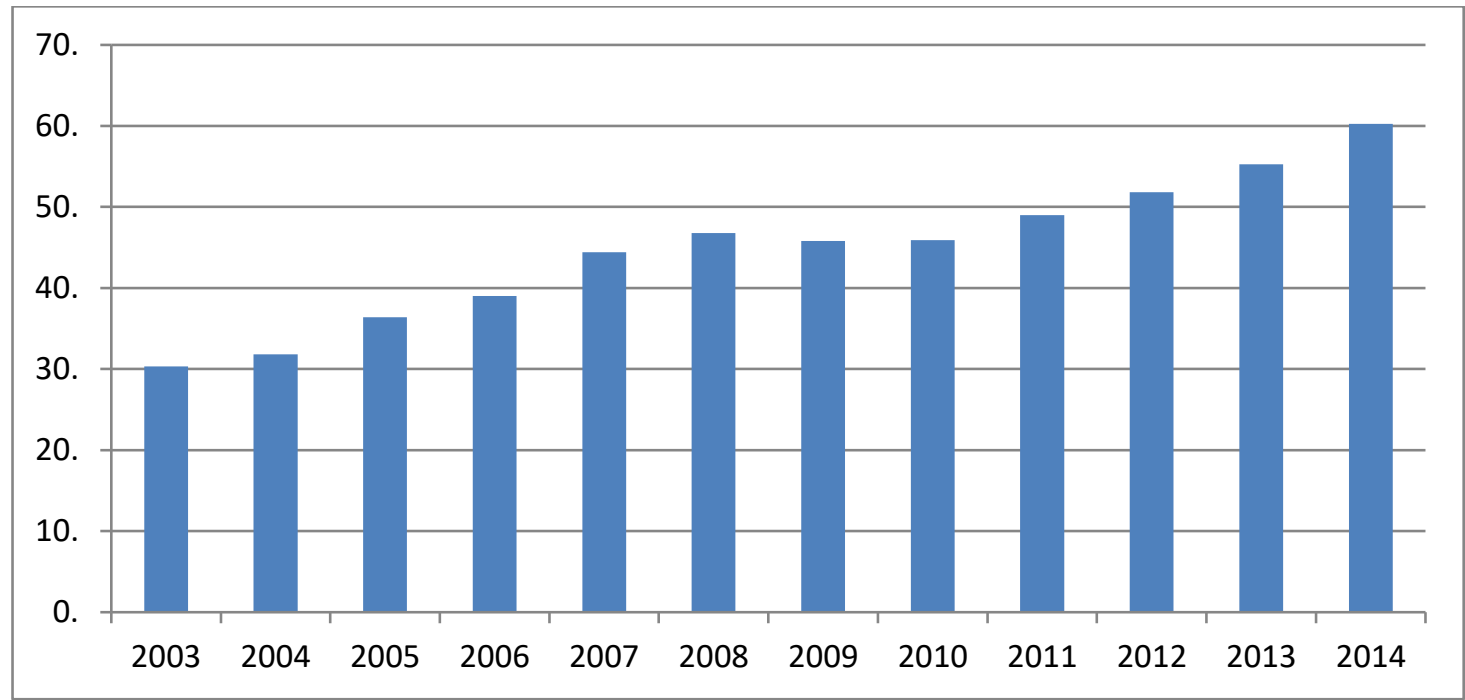

Figure 1: Total Giving to US Foundations 2003/2014 (Source: Statista)

In 2015 , the largest source of charitable giving came from individuals at $\$ 268.28$ billion, or $71 \%$ of total giving; followed by foundations ( $\$ 57.19$ billion or $16 \%$ ), bequests ( $\$ 28.72$ billion or $9 \%$ ), and corporations ( $\$ 18.46$ billion or $5 \%$ ). The average annual household contribution to nonprofits is $\$ 2,974$. In 2015 , the majority of charitable dollars went to religion $(32 \%)$, education $(15 \%)$, human services (12\%), grant-making foundations (11\%), and health (8\%).

\section{Non-Profit Sector Trends:}

The following are the major visible trends in the non-profit sector:

- The institutionalization of Corporate Social Responsibility (CSR): on example being the Ford Foundation, which has sponsored 43 Nobel Prize winners.

- The rise of enterprise-related foundations, like the Bill and Melinda Gates Foundation, founded in 1999, today, the largest of its kind in the world.

- Improved legislation in certain countries like Italy, China or Venezuela, that favors, motivates or forces CSR donations.

- The development of "crowdfunding" and various new methods of fundraising.

\section{Non-Profit Dynamics}

Greenaway and Vuong (2010) distinguish charities from other types of not-for-profit organizations by their staffing, as having more volunteers than paid workers, and their sources of revenue, based more on donations than fees, and state that they are consequently and particularly vulnerable to economic ups and downs.

Wooden (2005) says that on an individual (micro) level, the vast majority of donors she interviewed were enthusiastic and positive about the organizations they give to and about charities in general. Leonhardt (2008) refers to the "warm glow" theory, which states that people give money to feel the "glow" associated with being the kind of person who helps a worthy cause.

\section{Best Practices in Fundraising}

According to the National Philanthropic Trust, the Bill \& Melinda Gates Foundation is by far the largest such organization in the world, with over $\$ 44$ billion dollars in assets, followed by the Ford Foundation at 
\$12.4 billion. J. Paul Getty Trust, the Robert Wood Johnson Foundation, and Lilly Endowment Inc. round out the top five with over $\$ 9$ billion each. However, we are not interested so much in well-endowed philanthropy; we are interested in learning about fundraising and its best practices to try to point out what makes donations go up and down. In that sense, Wallace (2016) refers to an MIT fundraising drive which used Facebook's "likes" to generate US\$30,000, by following up on hits with an e-mailed newsletter to suitable followers, to turn them.

\section{Fundraising Practices and Research around the World}

Misener and Paraschak (2006) point to the impact of public policy in fundraising, particularly for amateur sports, which has led Canadian organizations to focus on survival, and which has resulted in a neglect of long-term initiatives. On the other hand, the Venezuelan Sports Ministry (2011) pushed for legislation that established a tax of $0.5 \%$ on corporate earnings to create the National Fund for the Development of Sports. It finances construction, events, and national team competitions, both nationally and internationally. It should be mentioned that the authors tapped into this fund since 2009 with great success, raising $\$ 4,000,000$ and helping their team win 266 world medals through 2017, thanks to corporate donors.

In terms of the dynamics of the Non-Profit Sector in the US, at the macro level, Curry, Rodin and Carlson (2012) would suggest that non-profit revenues swing with GDP. However, given the relevance of the sector in the economy, which puts it over such important industries as construction, transportation, information and arts and entertainment, it would seem only logical that they swing together. Berman, Brooks and Murphy (2006), nonetheless, contend that the macroeconomic variables do not appear to influence the short-run dynamics, suggesting that there is little real relationship between the economic cycle, using GDP and unemployment levels, and changes in the agencies' reliance on different sources of funds. They found that percentage changes in funding from year to year are relatively stable and are thus capable of being modeled using standard techniques. They suggest that non-profit revenues will depend on a cause's or an organization's public profile, networking, especially with religious organizations, and the sum of independent funding sources, including government support, that help diversify and stabilize fundraising in economic downturns.

Čačija (2013) went beyond the statistics and surveyed fundraisers to find that more than $70 \%$ of them linked economic crises to a drop in revenues. However, then, List (2011) stated that non-profit revenues react more to economic upswings than to downturns. So, the debate continues. Matsunaga, Yamauchi and Okuyama (2010) relate its size to the Theory of Government Failure. They centered their research on the health and education sectors and worked a cross-sectional analysis that ran data from 22 countries. Nonetheless, Sokolowski (2013) found that government funding has a positive effect on total revenues of the non-profit sector, as our own philanthropic experience also showed. Matsunaga and Yamauchi (2004) stated that the nonprofit sector has become widely recognized by researchers as having a critical and distinctive role in contemporary society; in the past, they say, it had been treated as a residual of other economic sectors, but has recently with increasing consistency, been thought of as an independent sector in its own right.

Indeed, Yi (2010) suggests that a better understanding of the factors that affect fundraising efficiency should be of great interest to charity managers, policy makers, and private donors, research has focused more on the micro than the macro view. Regrettably, perhaps, Wallace (2016) points to the fact that predictive modeling has concentrated on big-donor analytics, the micro view, largely aimed at the identification of potential donors.

On a mixed micro - macro view, Clark, Kotchen and Moore (2003) present a model that combines what they call the internal and external influences on donor behavior, pointing in the direction of our study. External variables, they say, consist of household income and standard socio-demographic characteristics. The internal variables determine their decision to donate. Wooden (2005) says that on an individual level, the vast majority of donors she interviewed were enthusiastic and positive about the organizations they give 
Quevedo et al., Adv. J Social Sci.; Vol. 5 Issue 1, pp: 1-9, 2019

to and about charities in general. Leonhardt (2008) refers to the "warm glow" theory, which states that people give money to feel the "glow" associated with being the kind of person who helps a worthy cause. In the end, Sergeant (2010) said that the need for the development of a comprehensive model of giving behavior has never been greater. Moreover, Lesley and Ramey (2016) point to the higher education sector's urgent need to improve fundraising.

\section{Scope of this Research:}

Considering the debate around the workings of the Non-Profit Sector, and the need for a better understanding of its dynamics, we set out to discover a model that describes what makes it move up and down. In specific terms, our research aimed to determine the macro variables that interact to produce funding, on a macro level, be it the general economy, or specific events like the Olympics or global warming, or others, to come up with an equation that should look like "Non-Profit Revenue $=\mathrm{a}+\mathrm{bX}+\mathrm{cY}+\mathrm{dZ}$ $+\varepsilon$ ". A predictive model of the US Non-Profit Sector would provide great strategic guidelines for fundraisers and NGO's, as well as to policy-makers, regarding the macro-dynamics that mediate over revenues. In specific, we intend to answer the following questions:

- What dynamics dictate non-profit revenues in fields such as higher education, amateur sports, health, the environment, and other social causes?

- How would this affect NGO strategies and fundraising processes?

- What policy improvements would best improve sector dynamics?

Our model presented graphically on Figure 2, below, builds on the micro-dynamics to provide an insight into the workings of social causes and the overall Non-profit Sector:

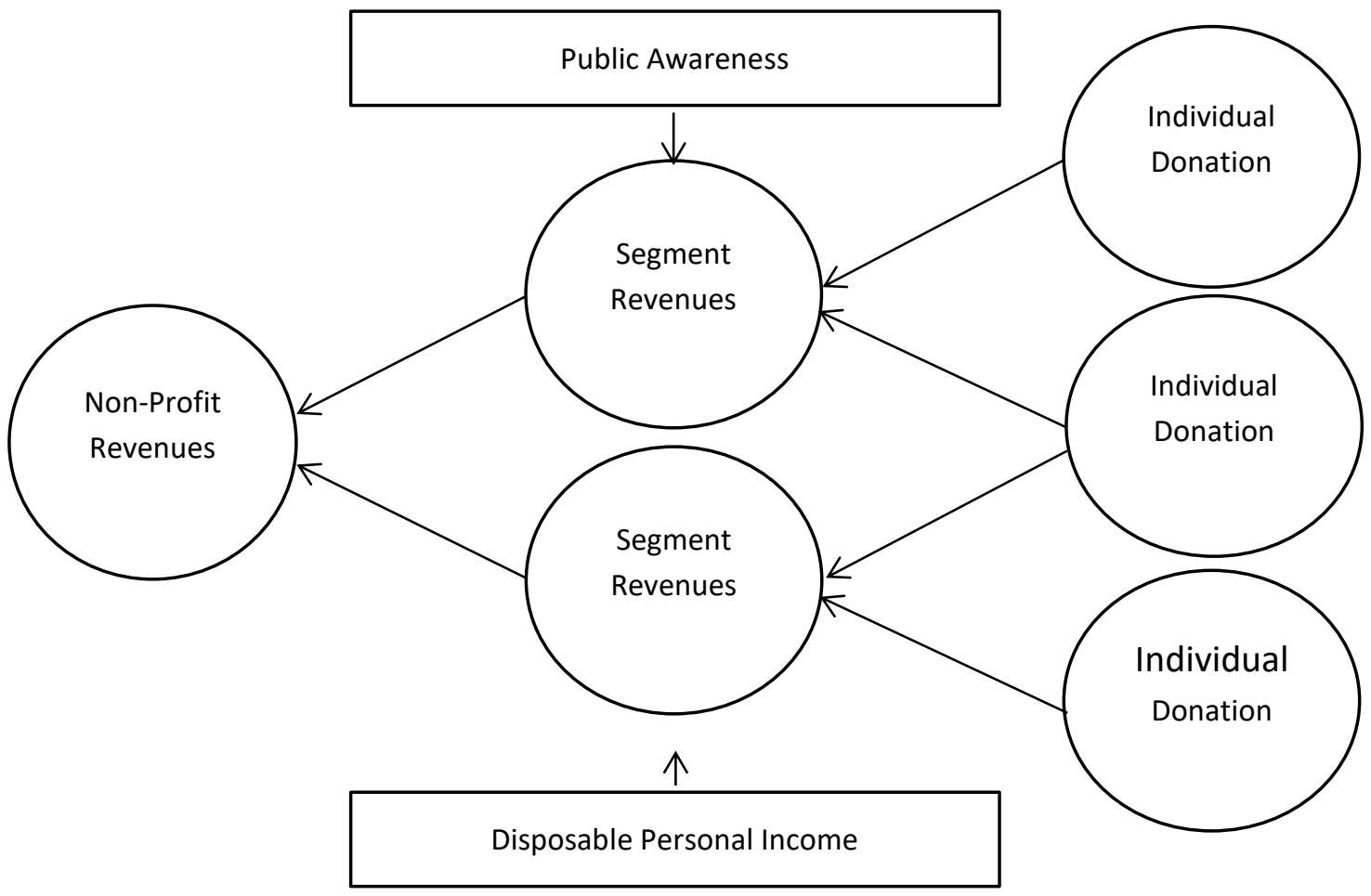

Figure 2: Our Model

\section{Our Hypotheses}

We propose that the more people know about a specific social cause (Karate in the Olympics, for instance, global warming, hunger in Africa, cancer, etc.), the more likely it will be that money will flow toward these. Extraordinary events, such as the Olympics, natural disasters, or an epidemic would boost public awareness, 
but there are other variables, like the economy, for instance, which must have also an effect on Non-Profit Revenues.

- Our Hypothesis (H1) is that total non-profit revenues respond to economic variables, and to the level of public awareness regarding social issues.

- We defined our Null Hypothesis (H0) as total non-profit revenues do not respond to the economy, nor to the level of public awareness regarding social issues.

\section{Research Findings}

Casting a wide net on different time series, Factor Analysis allowed us to pinpoint the most influential variables in the Non-Profit Sector. This procedure also led us to dismiss GDP, as it co-varied with DPI. In keeping with the model, but in the absence of a general measure of public awareness, which proved to be rather ethereal, too broad a term to capture and measure, we searched widely for correlations, monitoring Google searches as an initial indicator of public interest at least.

As seen on Table 1, below, we found significant correlations between Google searches on "Social Causes", DPI and Total Non-Profit Revenues, which kept us on the lookout for a better-fitting determinant.

Table 1: SPSS Output: Correlation Matrix

\begin{tabular}{|c|c|c|c|c|}
\hline \multicolumn{2}{|c|}{ Statistics } & $\begin{array}{c}\text { Google Searches on Social } \\
\text { Causes }\end{array}$ & $\begin{array}{l}\text { Total Non-Profit } \\
\text { Revenues }\end{array}$ & $\begin{array}{c}\text { Disposable } \\
\text { Personal Income }\end{array}$ \\
\hline \multirow{3}{*}{ Correlation } & $\begin{array}{l}\text { Google } \\
\text { Search }\end{array}$ & 1.000 & 0.849 & 0.860 \\
\hline & Total NPR & 0.849 & 1.000 & 0.772 \\
\hline & Disp. Income & 0.860 & 0.772 & 1.000 \\
\hline \multirow{3}{*}{ Sig. (1 tailed) } & $\begin{array}{l}\text { Google } \\
\text { Search }\end{array}$ & & 0.001 & 0.001 \\
\hline & Total NPR & 0.001 & & 0.004 \\
\hline & Disp. Income & 0.001 & 0.004 & \\
\hline
\end{tabular}

We also replicated the research of List (2011), who sought out relationships between macro-economic variables and total revenues of the non-profit sector. He discarded the correlation between GDP and NonProfit Revenues as obvious but did not explore Disposable Personal Income as a macro-economic variable. He seemed to stick to single variable searches and found a correlation between the S\&P index and NPR, working with lagged figures, and arrived at a correlation coefficient of 0.636 .

\section{Discussion}

Matsunaga and Yamauchi (2004) stressed the importance of the Non-Profit Sector in the US economy, which, as we saw, represents $5.4 \%$ of GDP. Yi (2010) highlighted the need to better understand the dynamics of fundraising, while Sergeant (2010) called for a model to explain them. Zappala and Lyons (2006), however, alerted as to the scarce flow of research into the sector, which -as Wallace (2016) pointed out- tends to concentrate in the micro aspects of big donor motivation. At the macro level, debate has impeded the acceptance of a simple model to explain Non-Profit Revenue behavior. Nissan, Castaño and Carrasco (2012) identified some macro research projects. List (2010) searched for macro-economic variables, as cited above, but could identify a single independent variable. Our model, albeit simple, as Cohen (1990) would recommend, pinpointed two clear factors that largely determine Non-Profit Revenue behavior, which should serve fundraisers to gain a better and much needed understanding of the dynamics of their economic sector. 
Quevedo et al., Adv. J Social Sci.; Vol. 5 Issue 1, pp: 1-9, 2019

\section{Conclusions}

As seen on Table 2, below, Non-Profit Revenues depend on Disposable Personal Income and Public Awareness, naturally referring to particular social causes, thus fitting the following model, capable of predicting $87 \%$ of the dependent variable's variance:

$$
\text { NPR Environment }=-4401.542+528.327(\text { DPI })+23.121(\text { TVCoverage })+\varepsilon
$$

Table 2: SPSS Output: Model Summary

\begin{tabular}{|c|c|c|c|c|c|}
\hline Model & R & R square & $\begin{array}{c}\text { Adjusted R } \\
\text { square }\end{array}$ & $\begin{array}{c}\text { Std. Error of } \\
\text { the Estimate }\end{array}$ & Durbin-Watson \\
\hline 1 & $.935^{\mathrm{a}}$ & .874 & .852 & 456.072 & 1.004 \\
\hline
\end{tabular}

a. Predictors: (Constant), TV coverage, Personal Disposable Income

b. Dependent Variable: Environmental Non-Profit Revenues (NPR)

Table 3 shows significance levels below 0.05 for all regression coefficients. The negative intercept we could very well interpret as relating to the fact that Non-Profits usually start out with a personal endowment from the fundraiser herself or philanthropist himself. The weight of each variable would suggest an order of conditions, that is, given the funds, first, people would tend to donate to better-known causes, second.

Table 3: SPSS Output: Regression Coefficients

\begin{tabular}{|l|c|c|c|c|c|}
\hline \multicolumn{1}{|c|}{ Model } & $\begin{array}{c}\text { Unstandardized } \\
\text { B }\end{array}$ & $\begin{array}{c}\text { Coefficients } \\
\text { Std. Error }\end{array}$ & $\begin{array}{c}\text { Standardized } \\
\text { Coefficients Beta }\end{array}$ & \multicolumn{1}{c|}{ Sig. } \\
\hline 1 (Constant) & -4401.542 & 1473.477 & & -2.987 & .012 \\
\hline Disposable Inco. & 528.327 & 142.949 & .405 & 3.696 & .004 \\
\hline TV coverage & 23.121 & 3.346 & .757 & 6.991 & .000 \\
\hline \multicolumn{2}{|c|}{ a. Dependent Variable: Environmental Non-Profit Revenue (NPR) } & & \\
\hline
\end{tabular}

After extracting these variables, our model above arrived at a Pearson's $\mathrm{R}$ of 0.935 , with almost perfect significance levels, and an enviable $\mathrm{R}^{2}$ of 0.87 . We proceeded with Confirmatory Factor Analysis, using AMOS, which indeed, ratified the fit of the model, as seen on Figure 3, below.

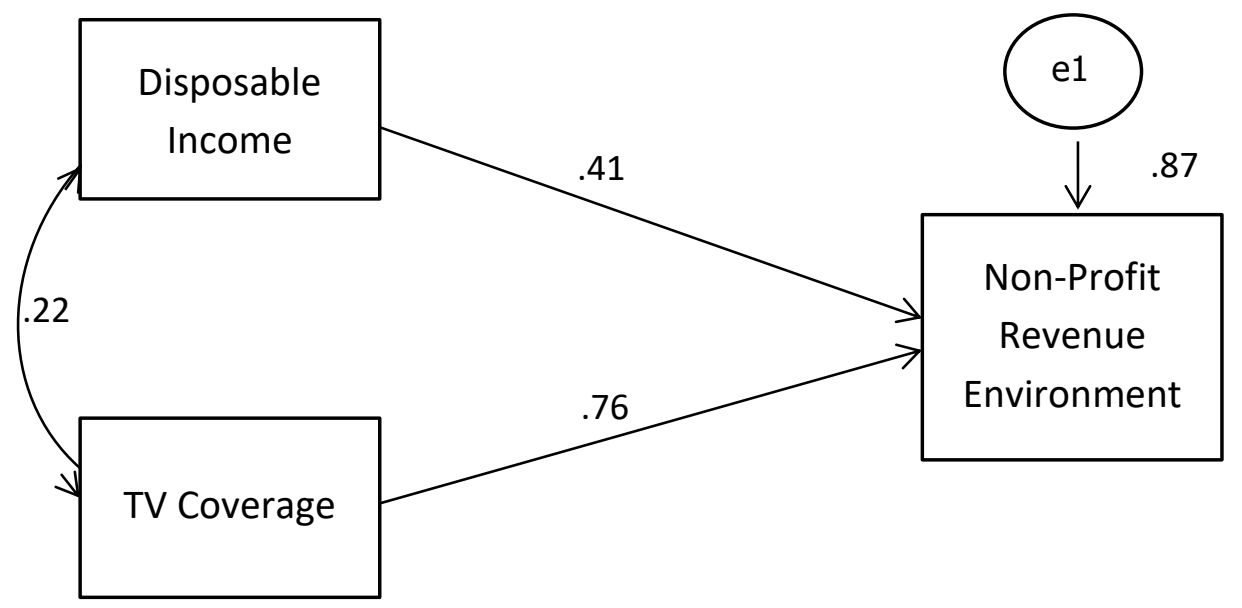

Figure 3: Amos Output: Confirmatory Factor Analysis Graph 
A Predictive Model for the US Non-profit Market; A Macro to a Micro Perspective

Significance levels proved consistent with SPSS findings, as seen on Table 4, below.

Table 4: Amos Output: Regression Weights

\begin{tabular}{|c|c|c|c|c|c|}
\hline & Regression Weights & Estimate & S.E. & C.R. & $\mathrm{P}$ \\
\hline NPRENV <--- & DPI & 528.327 & 131.494 & 4.018 & $* * *$ \\
\hline NPRENV <--- & TV & 23.121 & 3.078 & 7.513 & $* * *$ \\
\hline
\end{tabular}

Covariance between the independent variables turned to be statistically insignificant, as seen on Table 5, below ( $\mathrm{p}>0.05)$.

Table 5: Amos Output: Covariance Matrix

\begin{tabular}{|rrr|rrrrr|}
\hline \multicolumn{2}{|c|}{ Covariance } & & Estimate & S.E. & C.R. & P & Label \\
\hline DPI & $<-->$ & TV & 7.292 & 9.290 & .785 & .432 & \\
\hline
\end{tabular}

Fundraisers intuitively go searching for deep pockets, and that aligns perfectly, from a micro perspective, with one, and perhaps the most relevant of the macro determinants of Non-Profit Revenues found in this study, Disposable Personal Income, but fundraisers must also realize that they cannot influence DPI, that is, they cannot make their donors make money. However, the other determining factor in fundraising, Public Awareness, is indeed under the area of influence of fundraisers, hence the importance of effective communicational strategies to influence donors' decisions. People must be well informed about a social cause to effectively trigger donation, otherwise, moneys will flow elsewhere.

\section{Limitations}

Searching for a macro model for the Non-Profit Sector, this study was consequently limited to secondary data. Although our search found complete series for a single segment, the environmental cause, and for all the macro-economic variables that were cast in the original net, it was limited by the availability of data for other sectors, not so much in terms of revenues but about public awareness, in particular, in segments like education and amateur sports. It would be ideal if different social causes joined forces to contribute their TV exposure statistics to measure the fit of the model separately, for each fundraising purpose. It would also improve our understanding of the dynamics if moderators and mediators were factored into the model. We feel commitment to the cause would be a moderating factor in fundraising, and that the general economic outlook could act as mediator, however, primary data must be collected to pinpoint these relationships. In any event, if commitment did turn out to moderate donor intentions, fundraisers could still influence it through effective communication. In closing, Cohen (1990) said that simple is better, and this research did generate a simple, albeit perfectible model that explains the workings of the Non-Profit Sector.

\section{How to Cite this Article:}

Quevedo, F., \& Quevedo-Prince, A. (2019). A Predictive Model for the US Non-profit Market; A Macro to a Micro Perspective. Advanced Journal of Social Science, 5(1), 1-9. Doi: 10.21467/ajss.5.1.1-9

\section{References}

Ben-Ner, A. and Hoomissen, T. (1992), An Empirical Investigation of the Joint Determination of the Size of the For-Profit, Nonprofit and Government Sectors. Annals of Public and Cooperative Economics, 63: 391-415.

Berman, G., Brooks, R. and Murphy, J. (2006), Funding the Non-Profit Welfare Sector: Explaining Changing Funding Sources 1960-1999. Economic Papers: A journal of applied economics and policy, 25: 83-99.

Bialik, K. and Matsa K. (2017). Key trends in social and digital news media. Pew Research, FactTank, News in the Numbers.

Čačija, N. Lj. (2013). Fundraising in the context of nonprofit strategic marketing: Toward a conceptual model. Management, 18 (1), 59-78.

"Author Investigates Why People Give." Chronicle of Philanthropy, no. 18, 2005.

Cohen, J. (1990). Things I have learned (so far). American Psychologist 45. 1304-1312.

Curry, J., Rodin, S. and Carlson, N. (2012) Fundraising In Difficult Economic Times: Best Practices, Christian Higher Education, 11:4, 241252. 
Quevedo et al., Adv. J Social Sci.; Vol. 5 Issue 1, pp: 1-9, 2019

Daellenbach, K., Davies, J., \& Ashill, N. J. (2006). Understanding sponsorship and sponsorship relationships--multiple frames and multiple perspectives. International Journal Of Nonprofit \& Voluntary Sector Marketing, 11(1), 73-87.

Greenaway, K. E., \& Vuong, D. C. (2010). Taking charities seriously: a call for focused knowledge management research. International Journal of Knowledge Management, (4), 87.

Leonhardt, D. (2008). What Makes People Give? New York Times Magazine, 44.

List, John A. The Market for Charitable Giving. Journal of Economic Perspectives. Spring2011, Vol. 25 Issue 2, p157-180. 24p. 2 Charts, 3 Graphs.

Matsunaga, Y., \& Yamauchi, N. (2004). Is the Government Failure Theory Still Relevant? A panel analysis using US state level data. Annals Of Public \& Cooperative Economics, 75(2), 227-263.

Matsunaga, Y., Yamauchi, N., \& Okuyama, N. (2010). What Determines the Size of the Nonprofit Sector?: A Cross-Country Analysis of the Government Failure Theory. Voluntas: International Journal Of Voluntary \& Nonprofit Organizations, 21(2), 180-201

McKeever, Brooke Weberling (2013). From Awareness to Advocacy: Understanding Nonprofit Communication, Participation, and Support. Journal of Public Relations Research, Vol. 25 Issue 4, p307-328. 22p. 1 Diagram, 6 Charts.

Ministerio del Poder Popular para Deporte y Recreación (2011), Ley Orgánica del Deporte, Educación Física y Recreación, Gaceta Oficial No. 39.741, 23 de Agosto de 2011, República Bolivariana de Venezuela.

Misener, K. (2006) Fundraising capacity in Canadian national sport organisations: relationship-building and gender [Paper in Special Issue: Sport and the Third Sector Third Sector Review, Vol. 12, No. 2, 2006: 41-61.

Mena Report. (2017). Predictive Modeling for Fundraising. US Department of Agriculture. Bidding process concluded.

Mudura, M., Mudura T. and Secara O. (2015). Social Economy In Romania - European Perspective, Annals of Faculty of Economics, University of Oradea, Faculty of Economics, vol. 1(2), pages 599-604.

National Philanthropic Trust. (2016). Annual Report.

Nissan, E., Castaño, M., \& Carrasco, I. (2012). Drivers of non-profit activity: a cross-country analysis. Small Business Economics, 38(3), 303320.

Owens Erwin, C., \& Yarbrough Landry, A. (2015). Organizational Characteristics Associated With Fundraising Performance of Nonprofit Hospitals. Journal Of Healthcare Management, 60(2), 96-112.

Sokolowski, S. (2013). Effects of Government Support of Nonprofit Institutions on Aggregate Private Philanthropy: Evidence from 40 Countries. Voluntas: International Journal Of Voluntary \& Nonprofit Organizations, 24(2), 359.

Statista, available at https://www-statista-com.rlib.pace.edu/statistics/250889/total-amount-of-giving-by-foundations-in-the-united-states/

The Urban Institute (2015). The Non-profit Sector in Brief.

TVBroadcasting: https://www.tvb.org/Default.aspx?TabID=1903

Zappalà, G. and Lyons, M. (2006), Factors associated with fundraising dependency among nonprofit organisations in Australia. Australian Journal of Social Issues, 41: 399-417.

Wallace, N. (2016). Data and the Search for Big Donors. Chronicle of Philanthropy, 28(10), 7.

Wooden, R. A. (2005). What Makes Donors Give. Chronicle of Philanthropy, (05) December 2005.

Yi, D. T. (2010), Determinants of fundraising efficiency of nonprofit organizations: evidence from US public charitable organizations. Managerial and Decision Economis, 31: 465-475.

Publish your research article in AIJR journals-

$\checkmark \quad$ Online Submission and Tracking

$\checkmark$ Peer-Reviewed

$\checkmark$ Rapid decision

$\checkmark \quad$ Immediate Publication after acceptance

$\checkmark$ Articles freely available online

$\checkmark \quad$ Retain full copyright of your article.

Submit your article at journals.aijr.in
Publish your books with AIJR publisher-

$\checkmark \quad$ Publish with ISBN and DOI.

$\checkmark$ Publish Thesis/Dissertation as Monograph.

$\checkmark$ Publish Book Monograph.

$\checkmark$ Publish Edited Volume/ Book.

$\checkmark$ Publish Conference Proceedings

$\checkmark \quad$ Retain full copyright of your books.

Submit your manuscript at books.aijr.org 